\title{
Effects of Bean Ethanol Extract (Phaseolus Vulgaris L.) on Superoxide Dismutase Activity in Wistar Mice (Micetus Norvegicus) Hyperglycemia
}

\author{
Ade Putra Fratama Sinaga'), Syafruddin Ilyas'), Dwi Rita Anggraini3) \\ ${ }^{1)}$ Masters Program on Biomedics, Faculty of Medicine, North Sumatra University \\ ${ }^{2)}$ Department of Biology, FMIPA, University of North Sumatra \\ 3)Department of Anatomy, Faculty of Medicine, North Sumatra University
}

\begin{abstract}
Background: Aloxan tetrahyd micee causes free radicals and higher reactive oxidative species (ROS) production, being able to lead to reduce insulin secretion from pancreatic $\beta$ cells and receptor sensitivity in insulin-receptor cells resulting in hyperglycemia conditions. Bean extract ethanol can reduce oxidative stress. The purpose of this study was to determine bean's ethanol extract effectiveness in lowering blood sugar levels and increasing the activity of superoxide dismutase (SOD) enzyme.

Subjects and Methods: This was a randomized controlled trial (RCT) study. The samples were mice (Micetus norvegicus) of wistar strains randomized in five groups: P1-negative control, positive P2-control, P-3 ethanol extract group of 200mg / kgBW, P4-group 400mg / kgBW, $\mathrm{P}_{5}-$ group $600 \mathrm{mg} / \mathrm{kgBW}$. Dependent variables are blood sugar (mg/ dL) and superoxide dismutase enzymes. The independent variable is the bean extract of ethanol. Differences in blood sugar levels and superoxide enzyme levels of intergroup dismutase were tested by Anova test, followed by post hoc test, to determine the effectiveness of bean extract ethanol.

Results: This study showed a statistically significant decrease in blood glucose levels after ethanol extract of green beans $600 \mathrm{mg} / \mathrm{kg}$ BW from day 14 to day $28(\mathrm{p}<0.05)$. This study did not show a decrease in blood sugar levels after ethanol extract of green beans $200 \mathrm{mg} / \mathrm{kgBW}$ and $400 \mathrm{mg} /$ $\mathrm{kgBW}$ from day 7 until day 28 ( $\mathrm{p}>0.05$ ). Giving ethanol extract of green beans did not affect the activity of superoxide dismutase enzyme $(\mathrm{p}=0.830)$.

Conclusion: Giving ethanol extract of green beans $600 \mathrm{mg} / \mathrm{kgBW}$ effectively decrease blood sugar in male wistar mice (Micetus norvegicus) from day 14 to day 28. Giving ethanol extract of green beans $200 \mathrm{mg} / \mathrm{kgBW}, 400 \mathrm{mg} / \mathrm{kgBW}$, and $600 \mathrm{mg} / \mathrm{kgBW}$, is not effective to increase the activity of superoxide dismutase enzyme.
\end{abstract}

Keywords: Phaseolus Vulgaris L., blood sugar level, superoxide dismutase enzyme

\section{Correspondence:}

Ade Putra Fratama Sinaga. Masters Program on Biomedics, Faculty of Medicine, North Sumatra University. Email: adeputra535@ymail.com.

\begin{tabular}{l}
\hline BACKGROUND \\
\hline Hyperglycaemia is a state of very high \\
glucose concentration in the blood to \\
exceed normal. Hyperglycemia occurs due \\
to an absolute or relative insulin deficiency. \\
Insulin deficiency will cause disruption of \\
biochemical processes in the body that \\
decreases the entry of glucose into the cell \\
and increased release of glucose from the \\
liver into the circulatory system. Hyper-
\end{tabular}

glycemia is a state of elevated blood glucose levels beyond normal.

This state of hyperglycemia occurs in diabetes mellitus whose mechanism is caused by insulin deficiency and the effect on insulin receptors on cells. This uncontrolled state of hyperglycemia has a role as a cause of complications in diabetes mellitus (Gugliuci, 2000). 
Alloxan compounds are one of the toxic diabetogenic substances, especially to pancreatic beta cells, and when given to experimental animals such as mice, it can cause diabeticmice. Pancreatic beta cells damage causes the body not to produce insulin, causing blood glucose levels to rise (hyperglycemia occurs).

The condition of hyperglycemia according to Robertson et al. (2003) can result in the formation of reactive oxygen species (ROS $=$ reactive oxygen species). Excessive ROS can cause oxidative stress and can aggravate the destruction of pancreatic beta cells. Decreasing one of these components can lead to a complete reduction in antioxidant status and result in protection against ROS attacks being weak (Maslachah et al, 2008).

Antioxidants are bioactive compounds or substances that can serve to prevent, decrease oxidation reactions, break, block, stop, and stabilize free radicals (Margail, 2005). Antioxidants are distinguished by endogenous antioxidants and exogenous antioxidants. Antioxy and endogenous are generally enzyme-forming, eg superoxide dismutase (SOD), catalase, glutathione, peroxidase, and glutathione reductase. Exogenous antioxidants such as ascorbate, tocopherol, and carotene (Nayak, 2001).

But if it has too many free radicals, endogenous antioxidants will not be able to neutralize. Antioxidant deficiency can cause oxidative stress that leads to cellular damage and leads to various degenemiceive diseases (premature aging, cancer, etc.) (Evans et al., 2004).

A decrease in superoxide dismutase levels under stress conditions is highly unexpected, given the superoxidation function of dismutase as an antioxidant superoxide radical counter-inhibitor that increases in oxidative stress conditions.
Therefore, it is necessary to increase the levels of superoxide dismutase by eating foods containing antioxidants. During this time, diabetes is treated with glibenkamid, but it should be realized that the use of drugs in the long term often cause other effects on the body (Rahmawati et al, 2014).

Beans is a family member of Fabaceae and comes from America. Beans fruit is important as a human food because it contains carbohydmicees and fats, this plant also contains many protein materials, especially on the seeds. Combined with the staple foods that contain carbohydmicee, the type of food from beans can be used for malnutrition in Indonesia (Prasetyo, 2010).

Beans are an edible species of legumes. Fruit and seeds are used as vegetables. These vegetables are rich in protein content. The leaves are oval, sit spreading leaves. The inflorescence lies in the axillar or terminal with some white, pink and purple flowers. Pods up to $20 \mathrm{~cm}$ long, straight or generally slightly curved, fleshy when young, green or yellow, sometimes spotted or striped purple or reddish to purplish. The shape, size and color of the seeds are very diverse. Seeds round eggs, slightly rounded or kidney, black, brown, yellow, red and white (Cahyono, 2003).

Medicinal plants have been empirically used since immemorial for various diseases including diabetes mellitus. Beans (Phaseolus vulgaris L.) include potential medicinal plants to treat diabetes mellitus; the part used primarily is the fruit that contains flavonoids, served as an antioxidant (Ahkam, 2006). It is known that almost $80 \%$ of the total antioxidants in fruits and vegetables come from flavonoids, which can serve as an oxide superoxide capture, radical lipid peroxide. From previous study Sihombing et al, (2009) it has been known that the beans (Phaseolus 
vulgaris L.) have antioxidant activity. Provision of green beans cooked at a dose of $300 \mathrm{mg} / \mathrm{kg}$ showed significant results can lower blood glucose levels (Atchibri, 2010). According to Siahaan et al, (2016) flavonoids can reduce oxidative stress and have a hypoglycemia effect.

The active substances of phytosterols, namely $\beta$ sitosterol and stigmasterol in beans are able to stimulate the pancreas to produce insulin, causing the passage of the process of glucose metabolism by insulin resulting in decreased blood sugar levels previously increased in the body. So that the beans have the potential to control blood sugar levels in diabetes mellitus patients(Jannah et al., 2013).

\section{SUBJECTS AND METHOD}

This study used experimental study with posttest only control group design in male wistar mice. The sample was obtained by simple random sampling method which is divided into 5 groups, P1 (negative control), $\mathrm{P} 2$ (positive control), $\mathrm{P}_{3}$ (ethanol extract beans 200mg/ kgBW), P4 (400mg/ kgBW bean ethanol extract), $\mathrm{P}_{5}$ (600mg/ kgBW bean extract), blood glucose $>250 \mathrm{mg} / \mathrm{dl}$. When blood sugar levels increase, then it can be given the extract of ethanol beans until the 28th day.

Checking SOD serum of mice serum was performed using the Enzy Chrom ${ }^{T M}$ Superoxide Dismutase Assay Kit (ESOD100) on the 29th day.

\begin{tabular}{l}
\hline RESULTS \\
\hline The experimental animals used in this \\
study were healthy wistar mice with normal \\
blood sugar levels. Glucometer was used for \\
KGD measurements to ensure that normal \\
wistar mice. The KGD results have been \\
observed for up to 28 days of trials as seen \\
in Figure 1 .
\end{tabular}

\section{Blood Sugar level of Wistar Mice on 28}

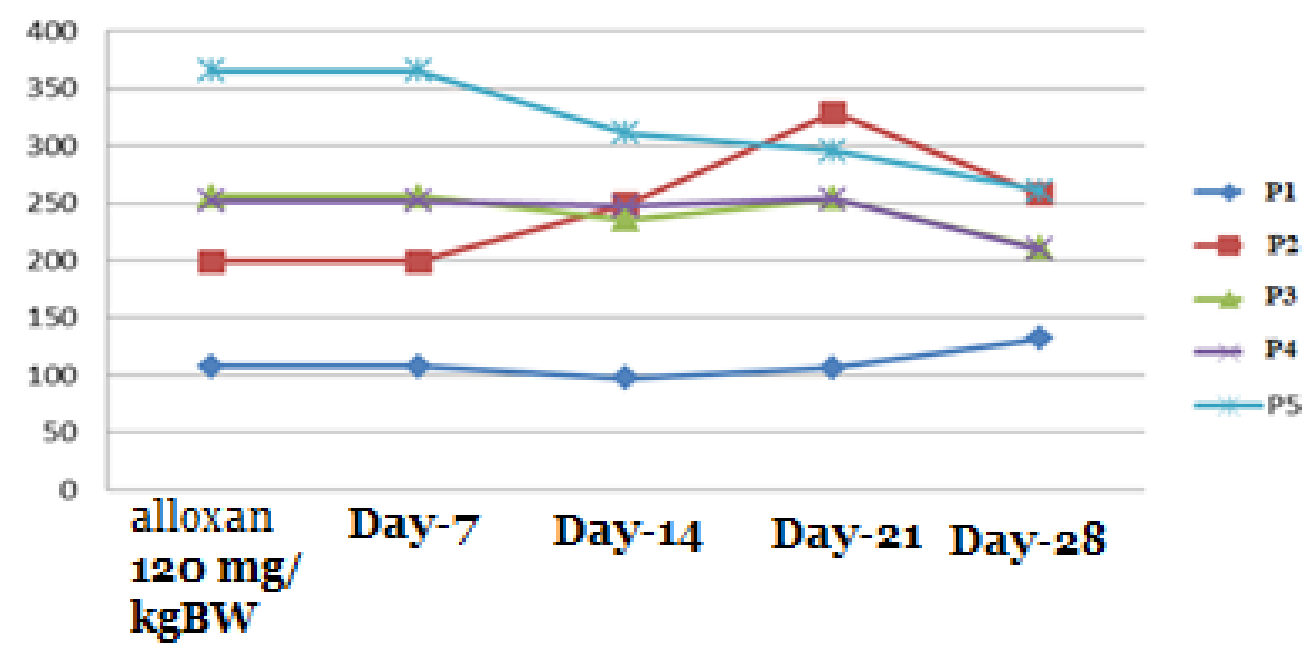

Picture 1. Diagram of KGD mice for 28 days Remarks: P1 (negative control), P2 (positive control), P3 (extract ethanol 200mg / kgBW), P4 (extract ethanol 40omg / kgBW), P5 (bean ethanol extract 6oomg / kgBW).

Based on Picture 1 above it was known that Alloxan destroyed pancreatic $\beta$ cells causing an increase in KGD. Differences in each treatment group were then tested by One Way Anova and Post Hoc Test using software SPSS 16. This study showed a significant decrease in blood glucose level after ethanol extract of green beans 600 $\mathrm{mg} / \mathrm{kgBW}$ from day 14 to 28 ( $\mathrm{p}<0.05$ ). This study did not show a decrease in blood 
Indonesian Journal of Medicine (2017), 2(2): 139-145

https://doi.org/10.26911/theijmed.2017.02.02.08

sugar levels after ethanol extract of green beans $200 \mathrm{mg} / \mathrm{kgBW}$ and $400 \mathrm{mg} / \mathrm{kgBW}$ from day 7 until day 28 ( $\mathrm{p}>0.05$ ).

Superoxide Disease Activity Dismutase Male Wistar Mice

The measurement data of the superoxide dismutase (SOD) enzyme activityof male

wistar mice after treatment for 28 days were shown in Table 1.

Based on Table 1 above, it was found that ethanol extract of green beans had no effect on superoxide dismutase enzyme activity $(\mathrm{p}=0.830)$.

Table 1. ANOVA test Result of Superoxide Dismutase data after treatment for 28 days

\begin{tabular}{lcc}
\hline Group & Average \pm SD $(\mathbf{U} / \mathbf{m l})$ & $\mathbf{p}$ \\
\hline P1 & $27.12 \pm 3.01$ & \\
P2 & $32.15 \pm 3.23$ & 0.830 \\
P3 & $29.12 \pm 2.79$ & \\
P4 & $25.28 \pm 3.97$ & \\
P5 & $31.90 \pm 2.08$ & \\
\hline
\end{tabular}

Description: P1 (negative control), P2 (positive control), P3 (200mg / kgBW ethanol extract), P4 (400mg / kgBW bean ethanol extract), $\mathrm{P}_{5}$ (60omg / kgBW ethanol extract).

\section{DISCUSSION}

Glucose levels in the blood or hyperglycemia without any good control will lead to one of the diabetes mellitus diseases (Murray et al, 2003).

It can also be influenced by physiological stress and environmental stress, such as stress due to the ethanol extract of green beans and the injection can cause stress where the stress will increase adrenaline then inhibiting the work of insulin so that the process of decreased blood sugar levels is inhibited. The results showed that giving of ethanol extract of green beans was no significant difference in the effect of superoxide dismutase activity of wistar mice. The highest increase of superoxide dismutase activity of wistar mice was found in group of $\mathrm{K} 2$ (positive control) compared with $\mathrm{P} 1$ (negative control), P3 (200mg / kgBW bean extract), $\mathrm{P}_{4}$ (400mg/ kgBW) and $\mathrm{P}_{5}$ ethanol extract of green beans $600 \mathrm{mg} / \mathrm{kgBW})$. Antioxidants in the chemical sense are electronizing compounds while the biological sense of antioxidants is all compounds being able to absorb free radicals and Reactive Oxygen Species (Suryohudoyo,
1993, Halliwel and Gutteridge, 1999; Arivazhagan et al., 2000).

Bean plants are plants containing flavonoid compounds that act as free radicals. In Andrieyani et al. (2015) it explains that binahong plants can lower blood glucose levels and increase the activity of SOD (Superoxide dismutase), where this binahong plants contain flavonoid compound, alkoloid, tannin, terpenoid, and saponin.

Similarly, Gisti et al. (2014) significantly increased an activity of SOD in treatment group of cardamom extract for 14 days proved that giving of cardamom extract was able to increase SOD activity of diabetic mice. Increasing the activity is associated with flavonoids. These findings support Quine, (2005) who suggested that the activity of SOD enzymes of mice given epicatechin (one type of flavonoids in tea) also increased. Some researchers report that flavonoids work as antioxidants.

Dembinska-Kiec et al. (2008) stated that flavonoids work as antioxidants by increasing the activity of SOD and also reported that flavonoids work as radical scavenger, for oxygen singlet radicals and 
lipid peroxidation (Ahmed, 2005; Astuti et al., 2009; Zhang et al., 2011). Flavonoids suppress peroxidase work, thus inhibiting ROS formation by neutrophils (Nijveldt et al., 2001).

Flavonoids also inhibit ROS formation by suppressing the action of some enzymes that produce it (Lukacinova et al., 2008). As a potential antioxidant, the flavonoid chains the metal and stabilizes it so that it can not catalyze the free radical oxidation reaction (Song et al., 2005).

Flavonoids muffle the reactivity of free radicals, thus directing the molecule to be more stable. Flavonoids also work donating hydrogen ions or electrons to superoxide anions, thus protecting lipoproteins, proteins, and DNA from oxidation (Nijveldt et al., 2001; Dembinska-Keic et al., 2008; Norshazila et al., 2010; Winarsi, 2007).

Giving ethanol extract of green beans $600 \mathrm{mg} / \mathrm{kgBW}$ effectively decrease the blood sugar in male wistar mice (Micetus norvegicus) from day 14 to day 28. Giving ethanol extract of green beans $200 \mathrm{mg} /$ $\mathrm{kgBW}, 400 \mathrm{mg} / \mathrm{kgBW}$, and $600 \mathrm{mg} /$ $\mathrm{kgBW}$, is not effective to increase the activity of superoxide dismutase enzyme.

\section{REFERENCES}

Ahkam S (2006). VCO Dosis Tepat Taklukan Penyakit. Jakarta: Penebar Swadaya.

Ahmed RG(2005). The physiological and biochemical effects of diabetes on the balance between oxidative stress and antioxidant defense system. Medical Journal of Islamic World Academy of Sciences. 15(1):31-42.

Andrieyani (2015). Identifikasi Senyawa Flavonoid dan Efek Terapi Ekstrak Etanol 70\% UmbiBinahong (Anredera Cordifolia (Ten) Steens) Terhadap Kadar Glukosa Darah Dan Aktifititas SOD (Superoksida dismutase)
Jantung Tikus Yang diinduksi Aloksan. Malang. Jurnal Alchemy, 4(5): 73- 78.

Arivazhagan PT, Thilakavathy C, Panneerselvam (2000). Antioxidant lipoate and tissue antioxidants in aged rats.J. Nutr. Biochem. 11: 122-127.

Astuti S, Muchtadi D, Astawan M, Purwantara B, Wresdiyati T (2009). Pengaruh pemberian tepung kedelai kaya isoflavon terhadap kadar Malonaldehid (MDA), aktivitas Superoksida Dismutase (SOD) testis danprofil $\mathrm{Cu}$, Zn-SOD tubuli seminiferi testis tikus jantan. J. Teknol. danIndustriPangan. 20(2):129-134.

Atchibiri, Ocho-Anin AL, Brou KD, Kouakou TH, Kouadio YJ, Gnakri D (2010). Screening for Antidiabetic Activity and Phytochemical Constituents of common bean (Phaseolus Vulgaris L.) Seeds. J Medicinal Plants Study. 4(17): $1757-61$.

Cahyono (2003). Kacang Buncis Teknik Budidaya Dan Analisis Usaha Tani, Kanisius, Yogyakarta.

Dembinska-kiec A, Mykkanen D, Kiec-Wilk B, Mykkanen H (2008). Antioxidant phytochemicals againts type-2 diabetes. British Journal of Nutrition. 99(1):109-117.

Evans MD, Dizdaroglu M, Cooke MS (2004). Oxidative DNA damage and disease: indiction, repair, and significance. Mutat Res 567:1-61.

Rahmawati G, Rachmawati FN, WinarsyH (2014). Aktivitas Superoksida Dismutase Tikus Diabetes yang Diberi Ekstrak Batang Kapulaga dan Glibenklamid. Scripta Biologica 3(1):19-23.

Gugliuci A (2000). Glycation as the glucose link to diabetic compilation, JAOA; 100(10): $621-34$. 
Halliwel B, Gutteridge JMC (1999). Free Radicals in Biology and Medicine. Oxford University Press. New York.

Jannah H, Sudarma IM, Andayani Y (2013). Analisis Senyawa Fitosterol Dalam Ekstrak BuahBuncis (Phaseolus Vulgaris L), J Chemistry Progress, 6(2): $70-5$.

Lukacinova A, Mojzis J, Benacka R, Keller $\mathrm{J}$, Maguth T, Kurila P, Vaško L, Racz O, Nistiar F. 2008. Preventive effects of flavonoids on alloxan-induced diabetes mellitus in rats. Acta Veterinaria Brno. 77(2):175-82.

Margaill I (2005).Antioxidant strategies in the treatment of stroke. Free Rad Biol Med, 39(4): 429- 443.

Maslachah L (2000). Pengaruh antioksidan probucol terhadap kadar malondialdehide (mda) dalam darah dan jumlah circulating endothel pada tikus yang menerima stressor. Thesis. Program PascaSarjana. Universitas Airlangga.

Nayak DU (2001). Antioksidant vitamin and enzymatic and sintetic oxygenderived free radical scevengersnin prevention and treatment of cardiovascular disease. Heart Dis (1); 28 45.

Nijveldt R, van Nood E, van Hoorn DEC, Boelens PG, van Norren $K$, van Leeuwen AM (2001). Flavonoids: a Review of probable mechanisms of action and potential applications. Am. J. Clin. Nutr. 74:418-425.

Norshazila S, Zahir S, Suleiman M, Aisyah MR, Rahim K (2010). Antioxidant levels activities of selected seed of Malaysian tropical fruits. Mal J Nutr. 16(1):149-159.

Prasetyo W (2010). Budidaya Tanaman Buncis. [Online] Tersedia: http://www.agrilands.net/read?full?agriwacan/budidaya/2010/11/23/- budidaya-tanaman-buncis.html $\quad[20$ Januari 2011].

Quine SD, Raghu PS (2005). Effects of (-) epicatechin, a flavonoid on lipid peroxidation and antioxidants in streptozotocin-induced diabetic liver, kidney and heart. Pharmacol Rep. 57(5):6105 .

Rahmawati G, Rachmawati NF, Winarsi H (2014). Aktivitas Suproksida dismutase (SOD) Tikus Diabetes yang diberi Ekstrak Batang Kapulaga Dan Glibenklamid. Scripta Biologika. 1(3):19 - 23. Robertson RP, Harmon J, Tran PO, Poitout $\mathrm{V}$ (2004). $\beta$-Cell glucose toxicity, lipotoxicity, and chronic oxidative stress in type 2 diabetes. Diabetes 53: S119S124.

Siahaan JM, Harahap U (2016). Effect of Ethanol Extract of Chayote (Sechiumedule.Jacq.Swartz) on the Activity of Glutathione Peroxide (GPx) in House Mice (MusmusculusL) Strain DD Webster Hyperglycemia Induced byStreptozotocin (STZ). Indonesian Journal of Medicine, 1: 47-52.

Sihombing CN,Wathoni N,Taofik R (2009). Formula Gel Antioksidan Ekstrak Buah Buncis (Phaseolus Vulgaris L.) Dengan Basis Aqupec505 HV. Sumedang: Universitas Padjajaran.

Song Y, Manson JE, Buring JE, Sesso HD, Liv S (2005). Associations of dietary flavonoids with risk of type 2 diabetes and markers of insulin resistance and systemic inflamation in women: a prospective study and cross-sectional analysis. Journal of American Collage of Nutrition. 24(5):376-384.

Suryohudoyo P (1993). Oksidan, Antioksidan dan Radikal Bebas. Laboratorium Biokimia Fakultas. Kedokteran. Universitas Airlangga. Surabaya.

Winarsi H (2007). Antioksidan Alami dan Radikal Bebas. Yogyakarta: Kanisius. 
Sinaga et al./ Effects of Bean Ethanol Extract (Phaseolus Vulgaris L.)

Zhang M, Cao J, Chen X, Wang Q (2011). Flavonoid contents and free radical scavenging activity of extract from leaves, stem, rachis, and roots of
Dryopteriserithrosora.Iranian Journal of Pharmaceutical Study. 11(3):991997. 